\title{
Who's Taking the Accounting Class? Leveraging Professional Skepticism While Teaching Accounting Online
}

Nancy L. Johnson, Augsburg College, USA

Faye Larson, St. Mary's University of Minnesota, USA

Anne DeMersseman, Chadron State College, USA

\begin{abstract}
The shortage of academically qualified accounting professors makes this a relevant time to increase the use of online tools for content delivery, assignment completion and assessment. Accounting students employed as teaching assistants (TA) can develop professional skills including skepticism, problem solving, analysis, organization and electronic documentation, while in academia. Certified Public Accountants (CPA) and educators are held accountable to high ethical standards through a code of conduct and academic integrity policies. This teaching case incorporates ethical decision making from an experience in an online virtual classroom where power differentials and analysis of student activity require research in a learning experience.
\end{abstract}

Keywords: Accounting; Teaching; Ethics; Online

\section{INTRODUCTION}

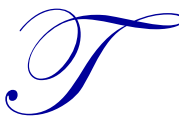

he American Institute of CPA's (AICPA) 2015 Trends Report indicated the number of U.S. Bachelor of Arts (BA) and Masters of Arts (MA) accounting graduates continues to trend upward nearly doubling from 45,095 in 2000 to 81,782 in 2014 (see Table 1). Graduates in master's programs are leading this growth, averaging a 16\% annual increase from 2000 - 2014 for a total of 27,359 graduates in 2014. The Bureau of Labor and Statistics (BLS) reported, in the 2015 Occupational Outlook Handbook, that employment of business and financial operations occupations in the United States (U.S.) is projected to grow 8 percent annually from 2014 to 2024 , adding about 632,400 new jobs. The report also includes findings that suggest a stronger regulatory environment is driving the demand for more accountants and auditors who prepare and examine financial documents. This would suggest a continued need for accountants and added support for faculty to teach accounting courses.

Table 1. AICPA 2015 Trends Report, Supply of Accounting Graduates

\begin{tabular}{l|c|c|c|c|c|c|c}
\hline Years & Bachelor's & \% Change & Masters & \% Change & Total & $\%$ Change \\
\hline $1999-2000$ & 37,115 & $-10 \%$ & 7,980 & $19 \%$ & 45,095 & $-6 \%$ \\
\hline $2001-02$ & 34,995 & $-8 \%$ & 9,700 & $11 \%$ & 44,695 & $-4 \%$ \\
\hline $2003-04$ & 40,420 & $9 \%$ & 13,340 & $5 \%$ & 53,760 & $8 \%$ \\
\hline $2006-07$ & 47,662 & $18 \%$ & 16,559 & $24 \%$ & 64,221 & $19 \%$ \\
\hline $2007-08$ & 48,968 & $3 \%$ & 17,491 & $6 \%$ & 66,459 & $3 \%$ \\
\hline $2009-10$ & 51,036 & $4 \%$ & 17,603 & $1 \%$ & 68,639 & $3 \%$ \\
\hline $2011-12$ & 61,334 & $20 \%$ & 20,843 & $18 \%$ & 82,177 & $20 \%$ \\
\hline $2013-14$ & 54,423 & $-11 \%$ & 27,359 & $31 \%$ & 81,782 & $0 \%$ \\
\hline
\end{tabular}

Source: http://www.aicpa.org/InterestAreas/AccountingEducation/NewsAndPublications/DownloadableDocuments/2015

These are healthy trends following the 1990's when the number of undergraduate accounting majors began to decline as other career fields, such as the attraction to the financial services field, siphoned off many accounting majors (Myers, 2006). In the immediate future, the number of retirements in accounting academia is likely to exceed the 
number of qualified replacements (Gary et al., 2011). The shortage of tenure-track faculty in accounting is specifically being observed in specialty areas of audit, systems, and tax (Behn, Ezzell, Murphy, Raybur, Stith and Strawser, 2012). To accommodate the increased student population, faculty will benefit from the use of standardized, repeatable course delivery systems and the use of TAs.

This teaching case will provide the accounting student, especially those serving as TAs, the platform to deliberate a situation based on a real-life ethics example in academia. The appropriate audience for this case includes undergraduate and graduate students studying for careers in the fields of accounting, teaching, technology, and human resources. This case provides the opportunity to practice critical thinking, problem solving, documentation, and recognizing the challenges and ethical impediments in the real world. It also supports Behn et al's (2012) recommendations to focus more academic research on relevant practice issues. This case is loosely based on a compilation of real situations. The names, specific situational information, course, and all other unique identifiers have been changed to protect the individuals inspiring this case, and the associated organizations, software vendors, etc.

\section{Academia and the Accounting Profession}

There are many overlapping skills essential in academia and the accounting profession. Both require the ability to provide assurance to help improve the reliability and relevance of information for assessment and decision making. Also, both require the ability to maintain independence and objectivity for unbiased judgement (Arens, Elder, Beasley, 2010). An astute accounting professional possess and continuously leverages the skill of professional skepticism to develop a comprehensive awareness and understanding of issues and situations. This capability is also beneficial for an educator when evaluating student work. In the accounting profession those certified (e.g. have passed all 4 sections of the uniform CPA exam and met the 150 credit hour requirements) complete an ethics exam and must earn continuing professional education (CPEs) in ethics each year to maintain active licensure status. In preparation, most accounting curriculum includes the study of ethics throughout.

\section{Student Approach to Learning}

Generally, students seeking a liberal arts education are doing so to become a more well-rounded individual and citizen. However, not all students are motivated in the same way or attend college for the same reasons. Some are motivated to attend college for academics and skill-building, while others come for just the experience of being in college. Student motivation toward engagement in academics also varies based on many factors. Attewell (2011) suggests that some students are motivated to take a course out of avoidance of some more challenging courses, and Campbell, Filling, Firch, and Lindsay (2015) cite the laziness of students may be due to deterioration of educational quality or rigor. Arum and Roska (2011) contend that some students are able to achieve relatively high marks with minimal effort in college.

Arum and Roska's (2011) analysis of how students reportedly spent their time indicated $9 \%$ attending class/labs, 7\% studying, $9 \%$ working, volunteering or attending clubs, $24 \%$ sleeping and $51 \%$ socializing. It is therefore safe to assume that student's prioritization and contributed efforts may lead to their seeking alternative methods and approaches to accomplishing the requirements of college coursework.

\section{Educational Content Delivery}

Accounting curriculum is designed to integrate the development of competencies suggested for the accounting field. Among those are critical thinking as defined by the ability to solve diverse and unstructured problems, to critique and render judgement along with the ability to deal effectively with imposed pressure and deadlines (Albrecht, Clark, Smith, Stocks and Woodfield, 1994). Generally, accounting students and professors are thought of as being ethical and critical thinkers, and having a curious brain. Accountants, especially skilled auditors, think differently from most business professionals. Their key skills include the ability to triangulate a set of seemingly unrelated facts into meaningful patterns. These are skills faculty require when seeking teaching assistant (TA) candidates. 
Software platforms, known as a course management system (CMS), are widely used by faculty for instruction and delivery of learning resources (Dutta, Roy and Seetharaman, 2013). A CMS typically includes a variety of online tools and environments for faculty to post class materials and manage gradebooks, and for students to engage in interactive assignments such as discussion boards, chat rooms, collaborative groups, and to submit homework. Examples of CMSs include Blackboard, Angel, Engage, Learning-Space, Moodle and OnCourse (Dutta, et al., 2013). Often faculty users choose a subset of CMS features depending on requirements, guidance and discovery from the institution (Yelon, 2006). Some of the greatest benefits of a CMS for faculty include repeatable distribution of learning tools and scalable access for a larger number of students to access and collaborate from a wide range of locations. TAs can support faculty by accessing the reporting tools that include common statistical metrics such as frequency of student use, length of preparing assignments, and login duration, all of which are subjective and may not reflect actual use (Dutta, et al., 2013).

Creating effective learning experiences is a vital part of accounting educators' work, and should be part of the peerreview process, faculty development plans, reward systems and other recognition and incentives (Behn et al., 2012). Dutta et al. (2013) identifies CMS user sophistication as the refinement or exhibition of higher levels of knowledge in the pattern of use and a more complex level of operation. Faculty adoption and use of a CMS remains driven by their perception of quality and usefulness, and expectation confirmation (Islam, 2011). Faculty use is also dependent on performance expectations and social influence by superiors to use technology (Pynoo et al., 2011). Dutta et al. (2013) studied the CMS faculty usage patterns over a five year period. Overall sophistication of faculty use remained unchanged for infrequent users but increased among frequent users. Experience has reflected that many faculty develop a false sense of user sophistication by merely posting notes and files for student access. The result is that there is a wide range of faculty and TA understanding of CMS systems and the specific data threads they collect.

As far back as 2009, the U.S. Department of Education established partnerships with companies such as Google, Apple, Microsoft, Pearson as well as other pools of resources designed to support continued learning (Davis and Ash, 2009). As a result, the current generation of students arriving on campuses each year are more at home with technology and less patient with traditional teaching methods (Behn et al., 2012). Fink (2013) identifies steps to helping students become self-directed learners using CMSs through specific actions such as internet research and trying to do something by oneself (p.173). Accounting students with aspirations of being a TA and a future auditor have an opportunity to practice and polish skills in making connections to seaming unrelated patterns using the CMS reporting tools.

E-learning and online delivery can have drawbacks. Faculty are required to think critically about the teaching and observation of patterns in an attempt to reduce the risk of student collaboration on independent assignments. Fisher et al. (2016) sheds light on the growing market of for-hire service providers online that are available to prepare assignments and take online courses for the registered student as the "ghost". To remediate these possibilities, the fully integrated E-Classrooms should require use of personally identifying tools such as Google Hangout, Skype, or VoiceThead where students are present or record their voice and video as part of an assignment. TAs can provide support for faculty in these areas to monitor and encourage ethical student conduct.

A method available in the CMS platform as a student identifier is the unique IP address. An IP address (IPv4) uses a 32-bit number, capable of providing roughly 4 billion unique numbers, to associate with a network. A "dotted decimal" notation separating number ranges with periods provides details about the network and the host address. To maintain uniqueness within the global space, IP addresses are publicly registered with the Network Information Center (NIC) to avoid address conflict. It is not uncommon for IP addresses for an organization to begin with the first two sets of common numbers (e.g., 121.719.xxx.xxx). There are various classes of IP addresses, and an organization could possibly have many thousands of IP addresses, but generally they would all contain some form of similar numbering pattern (e.g. 121.xxx.xxx.etc). A very similar IP address is not an indication of student collaboration in itself. There could be situations where on campus roommates, or students in the same lab on campus or on the same network server, could present virtually the same IP address. Those students who are entering the CMS outside of the college network (off campus) will have a non-college IP address associated with the login (e.g. a different numerical sequence) (IPLocation, n.d.). 


\section{CASE}

You have recently completed an internship in audit, developing your professional skeptic and data collection/documentation skills in reviewing client records for errors and variances. Upon returning to school you accept a TA position for an accounting professor whose professional career path includes having earned advanced degrees, a CPA licensure, many years of practice in both public and private accounting, and consultative engagements prior to becoming a fulltime educator. The professor has been teaching for several years before coming to this institution where the business practices are non-standard. Some of the reasons include; a sizable faculty population of long-term tenured career professors, no mandatory requirement for training and professional development in the tenured faculty evaluation process, and individual faculty have unilateral ownership of coursesand course development. There is inconsistent use of CMSs and TAs throughout the department. You specifically applied to work with this professor because of their advanced use of the CMS and online resources.

The institution has a strategic initiative to increase the diversity of course offerings and delivery platforms, to remain relevant in the marketplace. Market research has suggested that students prefer to take most of their classes from their home institution to alleviate the need for managing multiple email accounts and course management systems (e.g. Moodle, Blackboard, Angel, etc.), and the transferring of credits. In addition to face-to-face course offerings, faculty are encouraged to develop new sections of courses offered fully online, or as a hybrid to include elements of both face-to-face and online delivery.

Studies have shown that in online courses, feedback is critical (Kosba, Dimitrova, and Boyle, 2007) as students tend to feel more isolated than in a face-to-face classroom (Dutta, et al., 2013). Student evaluations in online courses are influenced by the quality and quantity of interaction with faculty; students perceive this as a more genuine interest in their learning (Dutta et al., 2013). As a result, the professor has developed highly standardized methods for teaching using the CMS to communicate, deliver content and instructions, and perform assessments to create an E-Classroom, a virtual enabled classroom with virtual office hours (Jarrahi framework, 2010, as cited in Dutta et al., 2013). As the TA you are expected to provide support in these areas to allow the professor increased time for instruction.

The professor teaches you how to leverage the CMS analytics to evaluate examinations and assess student results, trends, effectiveness of the learning experiences and overall engagement. As the TA you have great appreciation for the online learning platform and agree with studies showing students take more responsibilities for their learning in the online environment (Klein, Noe, and Wong, 2006). The course includes repeatable assignments such as autograded quizzes with large test banks delivering a collection of randomly selected problems to students. The scalable nature of the CMS allows for larger class sizes. The CMS captures extensive details about student activity including time stamping system and assignment access, the amount of time spent accessing learning activities, and student identifiers are in place such as Google Hangout, Skype or VoiceThread along with IP addresses.

In a fully online course it is critical for students to get started by logging into the class, begin working on the readings and learning assignments, and complete and submit homework by the due dates provided. These early actions in student engagement can enable faculty to anticipate trends and patterns for building in as many actionable steps as necessary (Carbajal Van Horn, Cullick, and McCurry, 2014). During the first weeks of class your role includes examining and assessing student login and assignment access patterns. You also engage students to create community through an introductory discussion forum. Here students introduce themselves and share a few personal details such as major, work experience, and other details. In this online class many have shared that they are taking the class from a remote or distance location. During your prior internship you learned about the value of a thorough documentation process. You make a log of student locations and time zones to build a schedule for on-campus and virtual online office hours to support students.

Your curiosity prompts you to explore many items in the analytics to gather meaningful data to construct and personalize student assessment and feedback. You discover that the CMS standard reports include a large number of student data points. Enough, so that for an inexperienced faculty or TA much of the value and unique patterns may be overlooked due to lack of understanding. From this information you were able to discern patterns of students taking online quizzes at the same time by sorting the results report in the CMS by time stamp. You notice that several 
students who self-identified as friend groups, were taking quizzes at the same time and possibly from the same location based on their IP addresses.

While reviewing student login and engagement patterns for the first week, one student IP address catches your attention. The student shared in the discussion forum that they are taking the course from a remote location, at least a two day drive away from campus. The student confirmed in the discussion forum that they are currently at that location and will not be participating in the optional live office hours or study groups. The IP address catches your attention because the student accessed the CMS via two different IP addresses. This is not uncommon as students typically access the system and prepare assignments from several different locations including home, school, coffee shops, etc. What you feel is uncommon is for someone who is in a remote location to be accessing the CMS from the IP address associated with the college, or very near to the college, which is what you feel is the case with this student.

Upon review, it appears that the student has accessed the CMS via an on-campus IP address completing a variety of activities in the class. It also appears that student is accessing the CMS from the remote IP address location and completing a variety of activities in the class. You note that the remote IP address does not change, but the on campus IP address varies slightly with each CMS access. By accidentally clicking on the IP addresses you reveal the city and state of origin. This confirms that a variety of IP address locations, which are many hours apart in distance, are used to access the CMS by the student in very close time periods. Prior audit experience and your professional skepticism prompt you to make note.

As you begin to reflect about the current situation, a few thoughts come to mind. Since a student is involved you reach for the University Code of Conduct, student handbook and the faculty handbook. You also are planning to become a CPA and future AICPA member and remember hearing about a code of ethics. Having worked for a CPA in public accounting in the internship, you are aware of the strict code of conduct that all CPAs, whether working in public accounting, private industry, higher education, unemployed or retired, are required to abide by. As you recall there are three sections of the code; the first section applies to CPA's working in public accounting, the third section applies to CPA's who are retired or unemployed, the second section applies to CPAs working in nonpublic areas, like you. You open your laptop and click on the link http://pub.aicpa.org/codeofconduct/Ethics.aspx\#. You review the code of conduct, section 0.300.010 - 0.300.070, which applies to all AICPA members, and Part 2, which applies to members in business and part 2.160.010, which applies to educators. After reading the code of conduct, you reflect on the current situation and contemplate the best way to proceed.

Case Questions: Complete the following 5 questions before reading the Additional Information section. (Instructor Note: The Additional Information provides the opportunity for students to explore more in-depth analysis in the areas of ethics, power differential, human resources and institutional policy.)

1) Identify the issues based on the facts in this specific case situation.

2) Identify the applicable rules, policies, and procedures (using the AICPA Code of Conduct as a CPA, and from a student or faculty perspective the university academic integrity policy, grievance policy and code of conduct policy).

3) Identify the stakeholders affected by the conclusions you have arrived at in Question 1 and how each is impacted.

4) What additional evidence is required to verify your conclusions reached in Question 1 and to ensure your conclusions are not biased?

5) Identify and document a comprehensive list of next steps.

\section{Additional Information}

Several of the employees of the institution have dependents who take classes at the college. You recall one college employee, who in addition to having teaching responsibilities is also in leadership at the school, as having shared with you that their child struggles to maintain focus for success in college. They indicated the child would possibly enroll in the course if developed for fully online because the student lived approximately 18 hours from campus. While you were not aware of the child's last name, you realize that the first name you have previously heard is the same as the student in question in the class. 
The professor you support has a strained relationship with the college employee. Since beginning your TA job the college employee's treatment toward you has changed to not providing clear guidance, and sharingunfounded biases about you and your professor with others. The individual is set in their seasoned ways of teaching, and while you know at some level appreciates you and your professor, has displayed signs of feeling threatened. The organizational structure of the institution (see Figure 1) places this college employee in a position of influence over your professor.

Figure 1. Organization Chart - Higher Learning

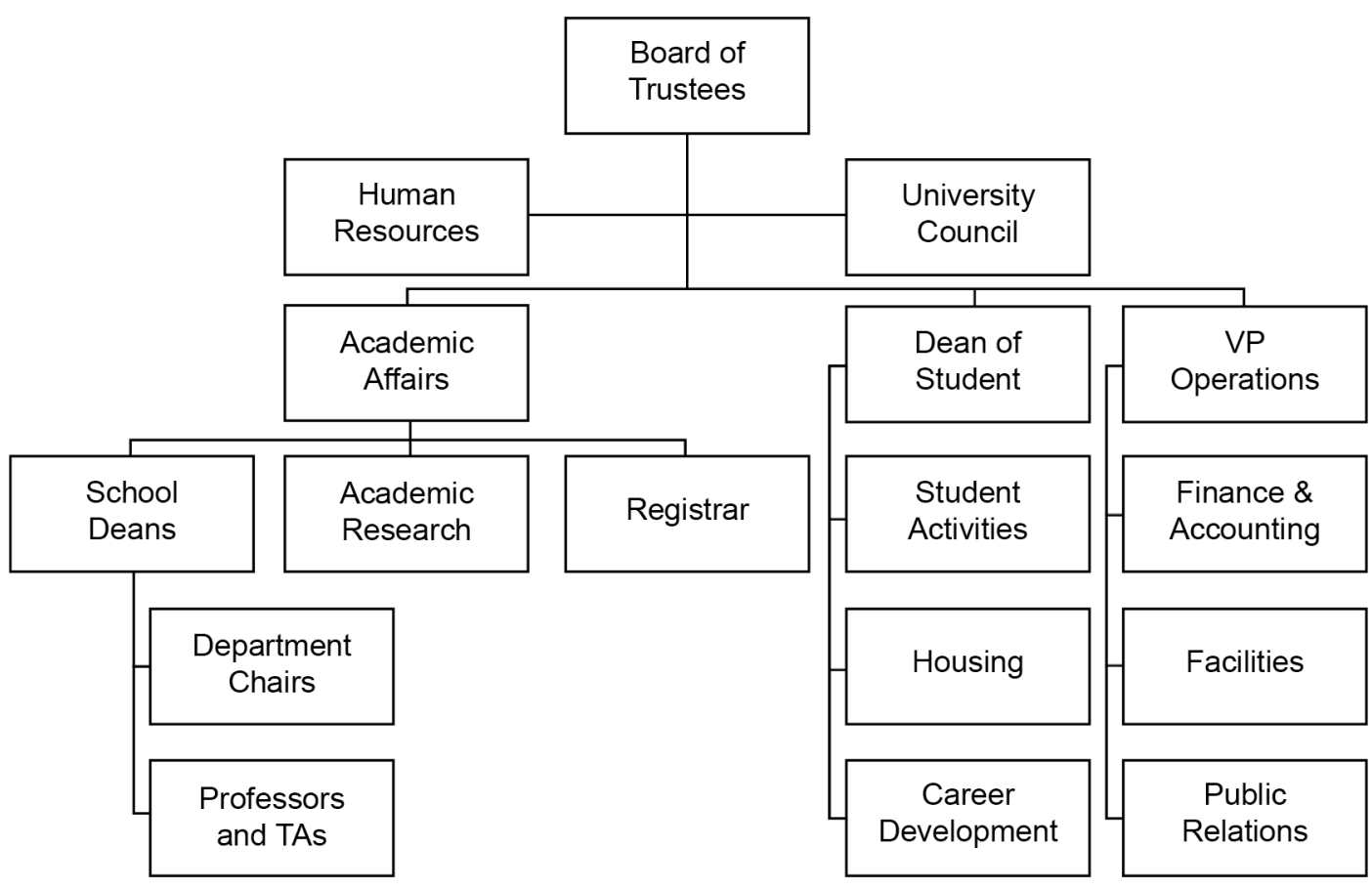

Additional Case Questions considering the new information:

6) Make a list of all possible explanations which could be occurring given the new facts?

7) Based on your answers in \#6, list alternatives available to you, and types of evidence required to substantiate or rule out items identified in \#6.

8) Update your list of your next steps above in light of this additional information. Include to whom to bring this information to, possible outcomes of each situation (legal, personal/professional, ethical), any and all obligation based on the codes of conduct within the instruction and the accounting profession.

9) What are you going to do? Include the implications related to your choice.

\section{Case Learning Objectives and Outcomes}

(Instructor Note: This case is designed for both individual and team preparation and presentation. The case questions raised allow the instructor to assign a paper, a summary of the questions and responses, presentation of facts and or a debate process where students defend positions taken).

The Learning Objectives and Outcomes

- Ability to discern seemingly unrelated facts into meaningful patterns.

- Identify and analyze an ethical issue in accounting, human resources, online and academic settings

- Identify the multiple ethical interests at stake in a real-world situation or practice 
- Articulate what makes a particular course of action ethically defensible

- Assess their own ethical values and the social context of problems

- Identify ethical concerns in academic, professional and human resource contexts

- Demonstrate the ability to document and communicate ethical concerns including academic integrity, use and citation of sources, and the objective presentation of facts

- Demonstrate knowledge of ethical values in non-classroom activities, such as work, internships, or professional associations

- Integrate, synthesize, and apply knowledge of ethical dilemmas and resolutions in academic settings

- Identify and analyze ethical and academic standards to which they are held accountable

- Perform decision making

\section{Case Solution Recommendation}

(Instructor Note: This case is designed for both individual and team preparation and presentation. The case questions raised allow the instructor to assign a paper, a summary of the questions and responses, presentation of facts and or a debate process where students defend positions taken).

1) Identify the issues based on the facts in this specific case situation.

\section{RESPONSE:}

AICPA
AICPA Code of Conduct: The sections that apply include the
following:

\subsubsection{Educational Services}

.01 Members who perform educational services, such as teaching full or part time at a university, teaching a continuing professional education course, or engaging in research and scholarship, are performing professional services and, therefore, are subject to the "Integrity and Objectivity Rule" [2.100.001]. [Prior reference: paragraph .06 of ET section $102]$.

\subsubsection{Integrity and Objectivity Rule}

.01 In the performance of any professional service, a member shall maintain objectivity and integrity, shall be free of conflicts of interest, and shall not knowingly misrepresent facts or subordinate his or her judgment to others (AICPA, 2014).

2.06 - Is a situation that poses a threat to you, as a member of AICPA, compromising your compliance with AICPA rules of conduct, primarily integrity and objectivity? Is the threat significant? What safeguards from your employer can you utilize? - i.e. - academic integrity policy, student code of conduct, faculty code of conduct, human resources etc.

2.000.020 - Suspicion of cheating may pose an ethical conflict. Watch for internal and external pressures. The individual must maintain student confidentiality, but have a responsibility to report any suspicion of fraud or cheating.
College

Student code of conduct for academic integrity.

A bargaining unit agreement that governs the handling of faculty concerns or misconduct.

In the case of a state institution whose employees are governed by employee policies set by a Board of Regents or State College System.

Employee Handbook: The appropriate sections could include employment contractual obligations for student workers, grievance policy, whistleblowing and other appropriate areas pertaining to ethical conduct for students and student workers.

(continued on next page) 
$\underline{\text { (continued from previous page) }}$

\begin{tabular}{l|l}
\hline \multicolumn{1}{l}{ AICPA } \\
$\begin{array}{l}\text { Whistleblowers: The AICPA is applicable if the institution is } \\
\text { governmental, including companies interacting with the } \\
\text { government. }\end{array}$ & $\begin{array}{l}\text { College } \\
\text { procedures in place at the university to ensure that the } \\
\text { students' position is heard. The student is required to remain } \\
\text { unbiased while presenting facts to ensure they make the } \\
\text { assumption of innocence. }\end{array}$ \\
\hline $\begin{array}{l}\text { Faculty Handbook } \\
\text { Some institutions will also employ an anonymous reporting } \\
\text { service such as BKD's IntegraReport system. While this } \\
\text { should be a last resort, it is important to know that these } \\
\text { vehicles exist. }\end{array}$ \\
$\begin{array}{l}\text { Human Resources recommendations should include access } \\
\text { first to institutional policy, reporting to Dean, VP of Academic } \\
\text { Affairs, and then to HR. }\end{array}$
\end{tabular}

The electronic footprint suggest that multiple individuals are preparing assignments for one student. Conclusions Drawn: The student is leveraging assistance (cheating) to earn college credit.

2) Identify rules, policies, and procedures (using the AICPA Code of Conduct as a CPA; and from a student or faculty perspective the university academic integrity policy, grievance policy and code of conduct policy

\section{RESPONSE:}

3) Identify the stakeholders affected by the conclusions you have arrived at in Question 1.

\section{RESPONSE:}

\begin{tabular}{|c|c|}
\hline Stakeholder & How Impacted \\
\hline The student in question & $\begin{array}{l}\text { The student may not be aware they are enrolled, or may be exercising unethical practices if a } \\
\text { different student is taking the class under their name. The student may be aware they are } \\
\text { enrolled and aware someone else is completing the course requirements for them. }\end{array}$ \\
\hline Other faculty & $\begin{array}{l}\text { Those who may have had the student in a future class and are assuming prior knowledge was } \\
\text { obtained. Faculty who had the student previously in class may have had the same experience, } \\
\text { but were not aware of it. }\end{array}$ \\
\hline Students in the class & $\begin{array}{l}\text { Current students who may be partnered or grouped with this student (or the real person } \\
\text { preparing assignments) may incur struggles and issues. }\end{array}$ \\
\hline Administration & $\begin{array}{l}\text { Institutional areas including financial aid and assessment committees, human resources if the } \\
\text { student has a work study position and all organizations the student may be involved in. }\end{array}$ \\
\hline Athletics & $\begin{array}{l}\text { Students who are involved in sports generally must maintain a specific grade point average and } \\
\text { code of conduct for eligibility. }\end{array}$ \\
\hline Future students & $\begin{array}{l}\text { Future students who may be influenced not to attend the institution as a result of negative } \\
\text { publicity. }\end{array}$ \\
\hline Human Resources & $\begin{array}{l}\text { Support, policy interpretation and enforcement as follows: } \\
\text { - What kind of investigation was conducted into any misconduct? } \\
\text { - What kind of retaliation protections were offered to the reporting party? (Retaliation } \\
\text { - wrotections should be spelled out in the Employee Handbook or Employee Policies) } \\
\text { - Will disciplinary actions need to be taken against the employee who is 'assisting' the } \\
\text { - Will disciplinary actions need to be taken against the department responsible for oversight? } \\
\text { - Were all steps documented appropriately should termination be the end result? }\end{array}$ \\
\hline You as the TA and student & You are placed in a compromising position. \\
\hline Faculty teaching the course & The faculty is placed in a compromising position. \\
\hline Department & The student may have scholarships tied to grade point average in their major. \\
\hline
\end{tabular}


4) What additional evidence is required to verify your conclusions reached in Question 1 and to ensure your conclusions are not biased?

\section{RESPONSE:}

\begin{tabular}{l|l}
\hline \multicolumn{1}{c}{ Area } & $\begin{array}{l}\text { Evidence } \\
\text { Technology }\end{array}$ \\
Education from technology staff pertaining to IP addresses, tracking and user identification.
\end{tabular}

5) Identify a comprehensive list of next steps.

RESPONSE: (Depending on the nature of the student's understanding of institutional structure a wide range of next steps could include but not be limited to the following:

\begin{tabular}{|c|c|c|}
\hline \# & Action Item & Process \\
\hline 1 & $\begin{array}{l}\text { Document the patterns you have noticed by creating screen shots of the log in history, student IP } \\
\text { addresses, assignments completed, discussion board post and all student communication confirming } \\
\text { the location of the student at times when course access is taking place. }\end{array}$ & Gather \\
\hline 2 & $\begin{array}{l}\text { Review student course schedule to determine if other online courses have been recently taken. Discuss } \\
\text { your concerns with those instructors and request they perform similar gathering steps which you are } \\
\text { currently undertaking to see if they see similar patterns. }\end{array}$ & Gather \\
\hline 3 & $\begin{array}{l}\text { Assignment Change: Create an assignment where students are required to log in, with a camera or } \\
\text { voice to narrate a solution. This could be a narrated PPT or video conference where students have } \\
\text { synchronous participation. Common technology includes Skype and Google Hangout and } \\
\text { VoiceThread. }\end{array}$ & Gather \\
\hline 4 & Review all findings, seeking patterns and inconsistencies. Create a timeline & Analyze \\
\hline 5 & $\begin{array}{l}\text { Make a list of all possible reasons the patterns identified could be occurring. Meet with technology } \\
\text { services to obtain confirmation of system and technology capabilities, understanding of log in and IP } \\
\text { address behaviors etc. }\end{array}$ & Verify \\
\hline 6 & $\begin{array}{l}\text { Meet with the faculty as soon as possible to present your suspicions. } \\
\text { Determine the appropriate individual within the organization who should be notified of the findings } \\
\text { and set up a meeting to discuss. }\end{array}$ & $\begin{array}{c}\text { Inform and } \\
\text { Report }\end{array}$ \\
\hline
\end{tabular}

6) What are the possible situations that could be occurring in these circumstances?

RESPONSE: Someone with access to the student's login information and university on-site computer system may be accessing and taking the course for student. This may include another student, university employee, your colleague or other student family member. The colleague is in a position of control over your faculty.

7) Based on your answers in $\# 5$, what alternatives are available to you, and what type of evidence is now required?

RESPONSE: Revisit the gather and analysis steps identified above. In reviewing the IP addresses, it may be possible to isolate the student login for comparison with the college technology department records of the same date and time to see if the colleague was also logged into the system. Documentation and verification of this may be uncomfortable and require resources which are not in place. Students should discuss possible issues pertaining to this processes, rights to privacy of the colleague and student.

8) Update your list of next steps in light of this additional information. Include whom to bring this information to, possible outcomes of each situation (legal, personal/professional, ethical), and any all obligation based on the codes of conduct within the instruction and the accounting profession. 
RESPONSE: Since you suspect academic integrity violations, and a conflict of interest with a leader in your school, you and the professor could take the concern directly to academic affairs. You can also take the matter to an institution leader outside of your school in the college (i.e. another department dean or chairperson). Human Resources would be contacted once suspicions have been confirmed.

9) What are you going to do? Include the implications related to your choice.

RESPONSE: Student responses will include a variety of answers.

\section{AUTHOR BIOGRAPHIES}

Nancy L. Johnson, CPA, MBA, is an Assistant Professor at Augsburg College, Minneapolis, MN. Her teaching areas of expertise include accounting, finance, systems design, organizational development, and change and strategic management. Research interests primarily focus on the scholarship of teaching and learning and leverage of online delivery. Ms. Johnson's professional experience also includes 20 years in the financial services industry and 10 years of business process standardization consulting.

Faye Larson, CPA (inactive), MBA is an Assistant Professor at St. Mary's University, Minneapolis, MN. Her teaching areas of expertise include accounting, audit, systems integration and taxation in both face-to-face and online delivery. Research interests primarily concentrate in areas of distance learning and leverage of course management systems analytics. Ms. Larson's professional experiences also includes in excess of 20 years in the accounting, audit and tax profession.

Anne DeMersseman is an Associate Vice President of Human Resources at Chadron State College, Chadron NE. She is also a Gallup-Certified Strengths Coach. Research interests include organizational development theory and the impacts and effects of power differential in higher learning. Additional professional experience includes 20 years of business process standardization, policies and procedures development, and human resources management.

\section{REFERENCES}

American Institute of Certified Public Accountants (2015). AICPA 2015 trends in the supply of accounting graduates and the demand for public accounting recruits (2015). Washington, DC. American Institute of Certified Public Accoutants.

Albrecht, W.S, Clark, D.C., Smith, J.M., Stocks, K. D., Woodfield, L.W. (1994). An accounting curriculum for the next century. Issues in Accounting Education. 9.2, Fall 1994. 401

Arens, A. A., Elder, R. J., and Beasley, M. S., (2010). Auditing and assurance services an integrated approach. $13^{\text {th }}$ ed. Pearson Prentice Hall. Upper Saddle River, NJ.

Arum, R., \& Roksa, J. (2011). Academically adrift: limited learning on college campuses. The University of Chicago Press, Chicago, IL.

Attewell, P. (2011). Riddle remains in academically adrift. Society 48(3): 225-226

Behn, B. K., Ezzell, W. F., Murphy, L. A., Raybur, J. D., Stith, M. T., Strawser, J. R. (2012). The pathways commission on accounting higher education: charting a national strategy for the next generation of accountants. Issues in Accounting Education. Vol. 27, 3.

Bureau of Labor Statistics Occupational Employment Statistics (2015). (BLS). Occupational Employment and Wages, May 2015. Retrieved from http://www.bls.gov/oes/current/oes251011.htm\#nat on 11/18/16.

Bureau of Labor Statistics Occupational Outlook Handbook (2015). (BLS). Retrieved from http://www.bls.gov/ooh/businessand-financial/home.htm on $8 / 16 / 16$

Campbell, A., Filling, S., Firch, T., \& Lindsay, D., 2015. Adrift in auditing class. American Journal of Business Education, Second Quarter, 2015, Vol 8, 2.

Carbajal Van Horn, M., Cullick, J. S., McCurry, S., (2014). Teaching with hackers handbooks: topics, strategies, and lesson plans. Bedford/St. Martins. Boston, MA.

Davis, M., Ash, K., (2009) Wine-flue plans put e-learning in the spotlight. Education Week 29.3, September 16, 2009. 1, 18,19

Dutta, A., Roy, R., Seetharaman, P. (2013). Course Management system adoption and usage: a process theoretic perspective. Computers in Human Behavior, 11/2013, Vol 29, Issue 6

Fink. L., D. (2013). Creating Significant Learning Experiences: An integrated approach to designing college courses. JosseyBass, A Wiley Brand. San Francisco, CA

Fisher, E., McLeod, A .J., Savage, A., Simkin, M. G. (2016). Ghostwriters in the cloud. Journal of Accounting Education. 34, $59-71$ 
Gary, R. F., Denison, C. A., and Bouillon, M. L. (2011). Can obtaining an accounting Ph.D provide a positive financial return? Issues in Accounting Education. Vol. 206, No. 1. P23-38.

IPLocation (n.d). Retrieved from https://www.iplocation.net/ip-address on 7/8/16.

Islam, A.K.M.N. (2011). The determinants of the post-adoption satisfaction of educators with an e-learning system. Journal of Information Systems Education, 22(4), 319-330.

Kim, J. \& Velez, M. (2011). Pathways through colleges adrift. In Arum, R., \& Roksa, J. (2011). Academically adrift: limited learning on college campuses. The University of Chicago Press, Chicago, IL.

Klein, H.J., Noe, RA. \& Wang, C. (2006). Motivation to learn and course outcomes: The impact of delivery mode, learning goal orientation and perceived barriers and enablers. Personal Psychology, 59(3), 665-702

Kosba, E., Dimitrova, V., \& Boyle, R. (2007). Adaptive feedback generation to support teachers in web-based distance education. User Model User-Adapted Interaction. 7(4), 379-413.

Myers, R. (2006). Teaching for the love of it; the joy of being an educator. Journal of Accountancy. June 21, 2006.

Pynoo, B., Devolder, P., Tondeur, J., van Braak, J., Duyck, W., \& Duyck, P. (2011). Predicting secondary school teachers' acceptance and use of ta digital learning environment: A cross-sectional study. Computers in Human Behavior, 27(1), $568-575$.

Yelon, S. (2006). Face-to-face or online? Performance Improvement, 45(3), 22-25. 


\section{NOTES}

